\title{
Left recurrent laryngeal palsy (Ortner's syndrome) in schistosomal pulmonary hypertension
}

\section{Paralisia do nervo laríngeo recorrente esquerdo (síndrome de Ortner) na hipertensão pulmonar esquistossomótica}

\section{José Roberto Lambertucci ${ }^{1}$, Pedro Henrique Prata $^{1}$ and Izabela Voieta ${ }^{1}$}

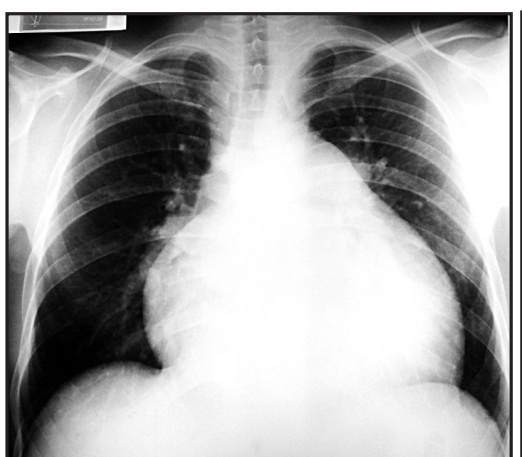

$\mathbf{A}$

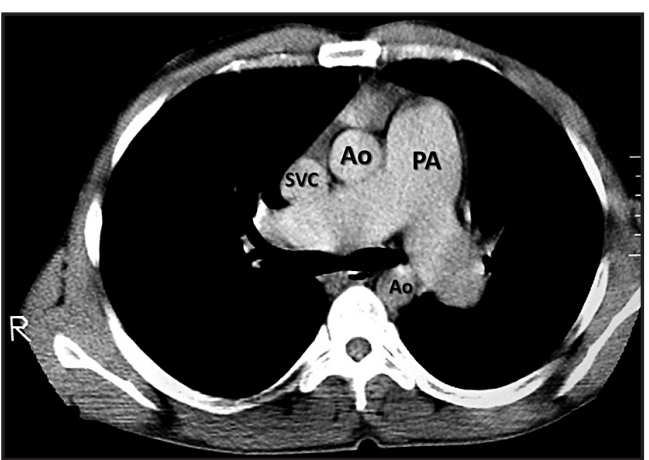

B

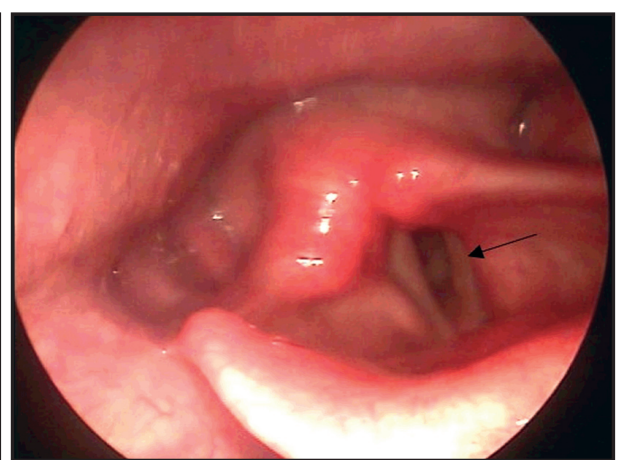

C
A 34-year-old man developed dyspnea and intermittent hoarseness of the voice that soon became constant, two years before admission to hospital. The disease evolved with progressive exertional dyspnea and palpitation. The patient comes from an endemic area for schistosomiasis mansoni in the State of Minas Gerais. Abdominal ultrasound and magnetic resonance of the liver showed periportal thickening suggestive of Symmer's fibrosis. A chest $\mathrm{x}$-ray showed enlargement of the heart and main pulmonary artery (Figure A). Echocardiography revealed a normal left ventricle, the right ventricle was dilated and the intraventricular septum moved paradoxically. Enhanced computed tomography revealed normal lung parenchyma and enlarged pulmonary arteries without lymph node swelling (Figure B, Ao=aorta; SVC=superior vena cava; $\mathrm{PA}=$ pulmonary artery truncus). Cardiac catheterization showed systolic pulmonary pressure of $130 \mathrm{mmHg}$. Dynamic laryngoscopy documented complete paralysis of the left vocal cord (Figure C, arrow). Ortner's syndrome or the cardiovocal syndrome is the name originally given to paralysis of the left vocal cord in cases of mitral stenosis associated with a large left atrium and pulmonary artery dilation. It has been suggested that the nerve is pinched between an enlarged dilated pulmonary artery and the aorta.

1. Graduation Course in Health Science: Infectology and Tropical Medicine, Faculty of Medicine, Federal University of Minas Gerais, Belo Horizonte, MG, Brazil. Address to: Dr. José Roberto Lambertucci. FM/UFMG. Av. Alfredo Balena 190, 30130-100 Belo Horizonte, MG, Brazil.

e-mail: lamber@uai.com.br

Received in $01 / 05 / 2010$

Accepted in 04/05/2010
O paciente, de 34 anos, notou dispnéia e rouquidão intermitente e, logo a seguir, permanente, dois anos antes de ser admitido ao hospital. A doença evoluiu com dispnéia progressiva aos esforços e palpitação. Ele mora em área endêmica para esquistossomose mansônica no Estado de Minas Gerais. O ultrassom do fígado e a ressonância magnética revelaram fibrose de Symmers. Havia aumento da área cardíaca e da artéria pulmonar na telerradiografia do tórax (Figura A). O ecocardiograma mostrou dilatação do ventrículo direito com movimento paradoxal do septo e com o ventrículo esquerdo normal. A tomografia computadorizada revelou o parênquima pulmonar normal e dilatação das artérias pulmonares sem aumento de linfonodos (Figura B; Ao=aorta; SVC=veia cava superior; $\mathrm{PA}=$ artéria pulmonar). A pressão sistólica pulmonar, medida durante o cateterismo pulmonar, era de $130 \mathrm{mmHg}$. A laringoscopia dinâmica demonstrou paralisia da corda vocal esquerda (Figura C; seta). A síndrome de Ortner ou síndrome cardiovocal são os nomes originais para a paralisia da corda vocal esquerda nos casos de estenose mitral com grande aumento do átrio esquerdo e dilatação da artéria pulmonar. A lesão tem sido atribuída à compressão do nervo laríngeo recorrente em seu trajeto entre a aorta e a artéria pulmonar dilatada.

\section{REFERENCES}

1. El-Ahmady LM. Left vocal cord paralysis in bilharzial pulmonary aneurysm. J Egypt Med Assoc 1974; 57:232-236.

2. Lambertucci JR, Carvalho VT, Silva LC. Pulmonary hypertension in schistosomiasis mansoni. Rev Soc Bras Med Trop 2006; 39:295-296.

3. Lambertucci JR, Serufo JC, Gerspacher-Lara R, Rayes AAM, Teixeira R, Nobre V, et al. Schistosoma mansoni: assessment of morbidity before and after control. Acta Trop 2000; 77:101-109. 